\title{
Detection of Blackleg Resistance Gene RIm1 in Double-Low Rapeseed Accessions from Sichuan Province, by Kompetitive Allele-Specific PCR
}

\author{
Liang Chai ${ }^{1}{ }^{1}$, Jinfang Zhang ${ }^{1}$, Wannakuwattewaduge Gerard Dilantha Fernando (iD ${ }^{2 *}$, Haojie Li $^{1}$, \\ Xiaoqin Huang ${ }^{3}$, Cheng Cui ${ }^{1}$, Jun Jiang ${ }^{1}$, Benchuan Zheng ${ }^{1}$, Yong Liu ${ }^{3}$, and Liangcai Jiang ${ }^{1 *}$ \\ ${ }^{1}$ Crop Research Institute, Sichuan Academy of Agricultural Sciences, Chengdu, Sichuan 610066, China \\ ${ }^{2}$ Department of Plant Science, University of Manitoba, Winnipeg, Manitoba R3T 2N2, Canada \\ ${ }^{3}$ Institute of Plant Protection, Sichuan Academy of Agricultural Sciences, Chengdu, Sichuan 610066, China
}

(Received on November 1, 2020; Revised on January 26, 2021; Accepted on February 1, 2021)

Blackleg is a serious disease in Brassica plants, causing moderate to severe yield losses in rapeseed worldwide. Although China has not suffered from this disease yet (more aggressive Leptosphaeria maculans is not present yet), it is crucial to take provisions in breeding for disease resistance to have excellent blackleg-resistant cultivars already in the fields or in the breeding pipeline. The most efficient strategy for controlling this disease is breeding plants with identified resistance genes. We selected 135 rapeseed accessions in Sichuan, including 30 parental materials and $\mathbf{1 0 5}$ hybrids, and we determined their glucosinolate and erucic acid content and confirmed 17 double-low materials. A recently developed single-nucleotide polymorphism (SNP) marker, SNP_208, was used to genotype allelic RIm1/rlm1 on chromosome A07, and 87 AvrLm1-resistant materials. Combined with the above-mentioned seed quality data, we identified $11 \mathrm{AvrLm1-resistant} \mathrm{double-low} \mathrm{rapeseed}$

*Co-corresponding authors.

L. Jiang

Tel) +86-28-84504235

E-mail)jlcrape@163.com

W. G. Dilantha Fernando

Tel) 204-474-8577

E-mail) dilantha.fernando@umanitoba.ca

ORCID

Liang Chai

https://orcid.org/0000-0002-6022-1927

Wannakuwattewaduge Gerard Dilantha Fernando

https://orcid.org/0000-0002-2839-1539

(c) This is an Open Access article distributed under the terms of the Creative Commons Attribution Non-Commercial License (http:// creativecommons.org/licenses/by-nc/4.0) which permits unrestricted noncommercial use, distribution, and reproduction in any medium, provided the original work is properly cited.

Articles can be freely viewed online at www.ppjonline.org. accessions, including nine parental materials and two hybrids. This study lays the foundation of specific $R$ gene-oriented breeding, in the case that the aggressive Leptosphaeria maculans invades and establishes in China in the future and a robust and less labor consuming method to identify resistance in canola germplasm.

Keywords : blackleg resistance, double-low rapeseed, KASP, Leptosphaeria maculans, Rlm1 gene

Handling Editor : Cecile Segonzac

Rapeseed (Brassica napus) is the second most important oilseed crop globally, after soybean (Glycine max) (Basunanda et al., 2010; Sun et al., 2018). Apart from edible oil and animal feed, rapeseed also provides raw material for biodiesel or industrial erucic acid production, as well as the landscape for tourism.

Blackleg, caused by two fungal pathogens, aggressive Leptosphaeria maculans or less (or non-) aggressive L. biglobosa (Fernando et al., 2016), is a severe disease in rapeseed and a major constraint to its production for many producing areas in the world, including Canada, Australia, and Europe (Fitt et al., 2006; Fu et al., 2019; Howlett, 2004). Blackleg causes a global economic loss of over $\$ 900$ million per growing season (Fitt et al., 2006, 2008). China, as another high rapeseed producing country, of which oilseed production accounts for approximately $30 \%$ of the total global yield, has not been plagued by blackleg to date (Liu et al., 2014), although there are few reports of non-aggressive L. biglobosa (Zhang et al., 2016b). However, as the international seed trades are becoming increasingly frequent, it is necessary for Chinese breeders to take provisions to safeguard the crop. To the best of our knowledge, blackleg 
is difficult to control with fungicides (Kutcher et al., 2010); thus, the most efficient and environmentally sound approach for controlling this disease is deployment of plant resistance genes prior to $L$. maculans incursions into China (Delourme et al., 2006; Zhang et al., 2014).

There are two types of resistance against blackleg in rapeseed: seedling resistance, which is a qualitative trait conferred by a major gene ( $R$ gene), and adult plant resistance (APR), which is a quantitative trait conferred by multiple minor genes (Zhang et al., 2016a). Researchers have suggested that the rotation of $R$ genes could be an efficient strategy to control blackleg (Marcroft et al., 2012), and the foundation of this is to validate the presence of $R$ genes in plants and to specify them. So far, at least $18 R$ genes in Brassica species have been identified (Zhang et al., 2016a); however, only three of them, i.e., Rlm2 (Larkan et al., 2015), LepR3 (Larkan et al., 2013), and Rlm9 (Larkan et al., 2020), were cloned. $R \operatorname{lm} 1$ is a single dominant $R$ gene (Fu et al., 2019), and its interaction with corresponding avirulence gene AvrLm1 in L. maculans provided the first genetic evidence for the "gene-to-gene" interactions (Ansan-Melayah et al., 1998). Fu et al. (2019) used $\mathrm{BC}_{1}$ and $\mathrm{F}_{2}$ populations and fine-mapped $R \operatorname{lm} 1$ gene in rapeseed by using single-nucleotide polymorphism (SNP) markers through kompetitive allele-specific PCR (KASP), a high throughput genotyping technology based on fluorescence (Semagn et al., 2014); then, an SNP marker (SNP_208) was developed that could distinguish Rlm 1 from allele $r l m 1$ by KASP. This allele SNP site (G for resistance while T for susceptibility) was located at the position of 19,989,284 bp on chromosome A07 and resulted in a missense variant in candidate gene BnaA07g27460D. That research provides a foundation for genotyping the allele Rlml/rmll in canola and related germplasm.

Double-low (low erucic acid and glucosinolates content) rapeseed oil is considered healthier for humans. In the last few decades, great gains in double-low rapeseed breeding have been achieved in China. In this study, we selected 135 rapeseed accessions, including 30 parental materials and 105 hybrids, to determine their glucosinolate and erucic acid contents; then, we performed KASP with the marker SNP_208 mentioned above to genotype these alleles from these rapeseed materials, screening out materials with a resistant $R \operatorname{lm} 1$ locus. Thus, we identified many double-low and AvrLm1-resistant germplasm that would be potential sources of germplasm to move forward in our breeding program.

Plant materials. The 135 rapeseed germplasms, consisting of 30 parental materials and 105 hybrids, were all bred by and kept in the Crop Research Institute, Sichuan Academy of Agricultural Sciences. None of the hybrids were derived from these parental plants. The seeds were sowed in September 2018, in experimental fields in the Xindu District $\left(30^{\circ} 47^{\prime} 10^{\prime \prime} \mathrm{N}, 104^{\circ} 12^{\prime} 12^{\prime \prime} \mathrm{E}\right)$ in the Sichuan Basin, with an annual average temperature of $16.2^{\circ} \mathrm{C}$ in humid subtropical monsoon climate. Each accession was planted in row of 8 plants, with $30 \mathrm{~cm}$ between plants within each row and between rows. Three biological replications were applied.

Seed quality determination. The seed quality characters, oil content, erucic acid content, and glucosinolate content were determined by near infrared spectroscopy (FOSS model 5000, NIR System Inc., Silver Spring, MD, USA), with the room temperature at $20-25^{\circ} \mathrm{C}$ and air humidity under $60 \%$. The parameters were described by Gan et al. (2003). Three biological repetitions were applied and standard deviation was calculated by MS Excel. "Double-low" was defined as erucic acid content $<2 \%$ of oil content and glucosinolate content $<30 \mu \mathrm{mol} / \mathrm{g}$ for parental plants or $<40 \mu \mathrm{mol} / \mathrm{g}$ for hybrids. For each accession, a specimencup of seeds (usually 6-7 g) were used for each time.

Genotyping of rapeseed germplasm. Leaves from each accession were sampled at the seedling stage. The total DNA was extracted by the cetyltrimethyl ammonium bromide method (Doyle and Doyle, 1990). The DNA quality was validated using a NanoDrop 2000 spectrophotometer (Thermo Scientific, Wilmington, DE, USA). Each DNA sample was then diluted to $20 \mathrm{ng} / \mu \mathrm{l}$.

Table 1. Primers of marker SNP_208 for KASP

\begin{tabular}{ll}
\hline Primer & \multicolumn{1}{c}{ Sequence } \\
\hline VIC & 5'-GAAGGTCGGAGTCAACGGATTCGTTAACAAACTCTGTCGCG-3' \\
FAM & 5'-GAAGGTGACCAAGTTCATGCTCCGTTAACAAACTCTGTCGCT-3' \\
COM & 5'-GGCGTCGATCAGGTGAGCC-3' \\
\hline
\end{tabular}

This marker is slight modified according to Fu et al. (2019).

SNP, single-nucleotide polymorphism; KASP, kompetitive allele specific PCR; FAM and VIC, two SNP alleles labelled with fluorescent tags Fam and Vic, respectively; COM, common reverse primer. 

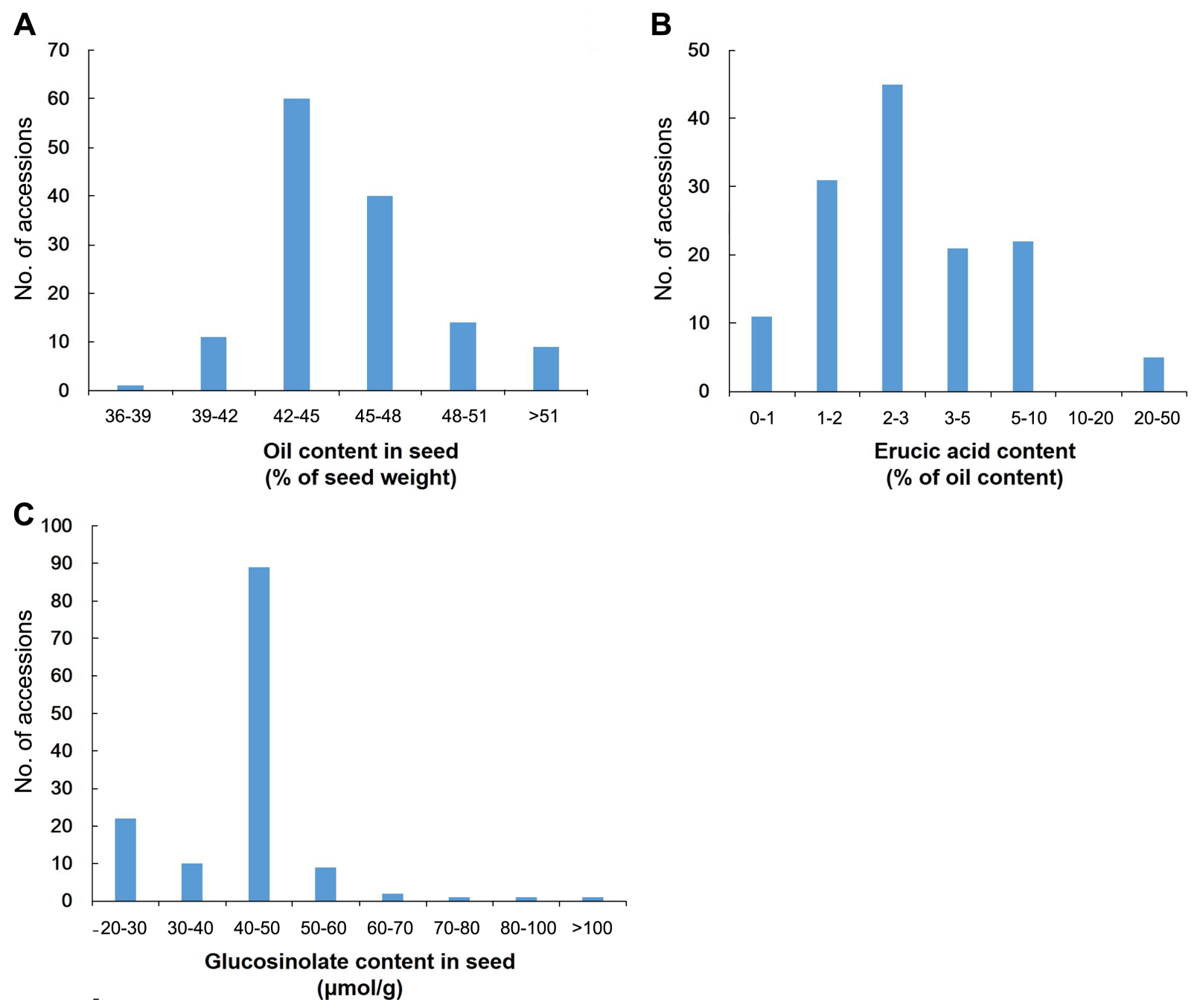

Fig. 1. Distribution of seed oil quality in the 150 selected accessions. (A) The oil content in seed of 150 accessions. (B) Erucic acid content in seed of 150 accessions. (C) Glucosinolate content in seed of 150 accessions.

The $4 \mu \mathrm{l}$ KASP reaction volume contained $2 \mu \mathrm{l}$ of $2 \times$ Taq DNA polymerase mix, $1 \mu \mathrm{l}$ of SNP primer mix (Table 1), and 4 ng DNA. KASP comprised a touchdown profile consisting of an initial denaturation at $94^{\circ} \mathrm{C}$ for $10 \mathrm{~min}$; followed by $94^{\circ} \mathrm{C}$ for $20 \mathrm{~s}, 61^{\circ} \mathrm{C}$ (with a $0.6^{\circ} \mathrm{C}$ drop per cycle) for $45 \mathrm{~s}$, and $72^{\circ} \mathrm{C}$ for $30 \mathrm{~s}$ for 10 cycles; then, 37 cycles of $94^{\circ} \mathrm{C}$ for $20 \mathrm{~s}, 55^{\circ} \mathrm{C}$ for $45 \mathrm{~s}$, and $72^{\circ} \mathrm{C}$ for $30 \mathrm{~s}$; with a final extension of $72^{\circ} \mathrm{C}$ for $10 \mathrm{~min}$. The PCR was performed on a Bio-Rad MyCycler (Hercules, CA, USA), and then the fluorescence information was collected by KASP Mix (LGC, type 1536) with Omega F plate reader (LGC, Teddington, UK). The KlusterCaller software (LGC) was used to read the fluorescence information and analyze it.

The analysis of the physical and chemical properties for the protein of candidate gene was performed using DNAMAN 6.0 (Lynnon Biosoft, Quebec, Canada).
Oil content, erucic acid, and glucosinolate content in the seed. We measured three important characteristics of the seeds from the 135 accessions: the oil content, erucic acid, and glucosinolate content. The oil content of the seeds from 135 accessions varied from $38.29 \%$ to $55.61 \%$ (Fig. 1A), and pin-130 represented the highest value (Supplementary Table 1). The $42-45 \%$ group showed the highest number of accessions, at $60 ; 12$ accessions had oil content over $50 \%$. The erucic acid content varied significantly among accessions. Accession pin-112 showed the lowest erucic acid content at only $0.39 \%$, while the highest value was $45.62 \%$ in accession pin-121 (Supplementary Table 1). In total, 42 accessions represented erucic acid contents lower than $2 \%$ (Fig. 1B), which was the defined as "low erucic acid content". We found that 22 accessions had glucosinolate contents lower than $30 \mu \mathrm{mol} / \mathrm{g}$, while 10 accessions rep- 
Table 2. The characters of the seeds from the 17 double-low accessions

\begin{tabular}{lcccc}
\hline Accession type & Sample ID & $\begin{array}{c}\text { Oil content in seed } \\
\text { \% of seed weight })\end{array}$ & $\begin{array}{c}\text { Erucic acid content } \\
(\% \text { of oil content })\end{array}$ & $\begin{array}{c}\text { Glucosinolate content } \\
(\mu \mathrm{mol} / \mathrm{g} \text { in seed })\end{array}$ \\
\hline Parental plant & pin-101 & $48.24 \pm 1.28$ & $1.39 \pm 0.31$ & $26.13 \pm 1.17$ \\
& pin-102 & $46.64 \pm 1.24$ & $1.18 \pm 0.41$ & $24.96 \pm 1.05$ \\
& pin-103 & $45.8 \pm 2.14$ & $1.65 \pm 0.78$ & $26.92 \pm 2.01$ \\
& pin-104 & $49.1 \pm 1.06$ & $0.55 \pm 0.26$ & $28.84 \pm 1.49$ \\
pin-105 & $47.8 \pm 0.93$ & $1.35 \pm 0.53$ & $27.11 \pm 1.06$ \\
& pin-109 & $44.95 \pm 2.17$ & $1.39 \pm 0.49$ & $23.49 \pm 3.49$ \\
& pin-111 & $44.61 \pm 0.59$ & $0.88 \pm 0.66$ & $22.75 \pm 0.53$ \\
pin-113 & $48.64 \pm 1.63$ & $1.48 \pm 0.76$ & $29.93 \pm 1.66$ \\
pin-115 & $49.15 \pm 0.82$ & $0.65 \pm 0.49$ & $27.85 \pm 1.8$ \\
pin-116 & $47.13 \pm 2.58$ & $1.68 \pm 1.61$ & $23.26 \pm 0.91$ \\
pin-128 & $49.89 \pm 0.29$ & $0.68 \pm 0.43$ & $27.85 \pm 2.29$ \\
pin-129 & $52.9 \pm 1.26$ & $0.42 \pm 0.42$ & $28.39 \pm 0.97$ \\
pin-130 & $55.61 \pm 1.15$ & $0.65 \pm 0.65$ & $27.21 \pm 3.03$ \\
pin-131 & $52.82 \pm 1.5$ & $1.36 \pm 1.36$ & $25.21 \pm 1.17$ \\
pin-10 & pin-80 & $41.87 \pm 1.57$ & $0.79 \pm 0.12$ & $39.48 \pm 1.9$ \\
pin-119 & $42.03 \pm 1.3$ & $1.5 \pm 0.73$ & $39.97 \pm 0.73$ \\
& $49.04 \pm 0.47$ & $1.37 \pm 0.7$ & $28.13 \pm 2.22$ \\
\hline
\end{tabular}

Values are presented as mean $\pm \mathrm{SE}$.

resented contents ranging 30 to $40 \mu \mathrm{mol} / \mathrm{g}$ (Fig. 1C). The "low glucosinolate content" for rapeseed is usually defined as lower than $30 \mu \mathrm{mol} / \mathrm{g}$ in the seeds of parental plants and lower than $40 \mu \mathrm{mol} / \mathrm{g}$ for hybrids; the definition of "low erucic acid content" adopts the same standard for both parental plants and hybrids, at $2 \%$ of the oil content. According to this, fourteen parental plants (pin-101, pin-102, pin-103, pin-104, pin-105, pin-109, pin-111, pin-113, pin115, pin-116, pin-128, pin-129, pin-130, and pin-131) and three hybrids (pin-10, pin-80, and pin-119) were identified as "double-low" (Table 2). In China, for edible oil, only the registered double-low rapeseed are currently allowed to be commercially released; while the hybrids, usually F1 hybrids derived from specific parental materials, are candidates for commercial use, which requires quality testing before registration.

Genotyping. The allelic SNP was genotyped using KASP, and the positive samples were categorized mainly into three clusters (Supplementary Table 2): homozygous resistance $(\mathrm{G} / \mathrm{G})$, heterozygous $(\mathrm{G} / \mathrm{T})$, and homozygous susceptible $(\mathrm{T} / \mathrm{T})$. Among the 30 parental plants, $18(60 \%)$ were identified as resistant, 8 were identified as susceptible, and the other 4 were negative, which meant it was neither $\mathrm{G}$ nor $\mathrm{T}$ on that particular locus; additionally, all 18 resistant samples were homozygous. In the 105 hybrids, 69 materials $(65.7 \%)$ were clustered into a resistance group, including
Table 3. Number of lines for each genotype at the Rlm1 locus

\begin{tabular}{lcccc}
\hline & G/G & G/T & T/T & Negative \\
\hline Parental plant & 18 & 0 & 8 & 4 \\
Hybrid & 52 & 17 & 29 & 7 \\
\hline
\end{tabular}

Negative means it was neither G nor T on this locus.

52 homozygous samples and 17 heterozygous ones. We found 29 samples identified as susceptible, and the other 7 samples were negative (Table 3, Supplementary Table 2). This Rlm1-containing frequency seems higher than earlier reported by Zhang et al. (2016b). This is to be expected, as they used germplasm from mainly Anhui Province; herein, the materials tested were to breed double-low rapeseed suitable for Sichuan climate. It is common to have different parental germplasm in each breeding program, and China's breeding material is no different from other countries in that. Some of them are progenies of common main parents (also known as backbone parental plants). This is a longterm selection process, so it is unavoidable to result in similar genetic background to some extent; thus, within such a range, it can result in higher $R \operatorname{lm} 1$-containing frequency, which is good news for Sichuan's rapeseed/canola breeders.

Combined with the above-mentioned seed quality data, nine double-low parental materials (pin-101, pin-105, pin109, pin-111, pin-115, pin-116, pin-128, pin-129, and 
pin-130) as well as two double-low hybrids (pin-80 and pin-119) were identified harboring allelic $R \operatorname{lm} 1$. Rlm 1 conferred resistance to AvrLm1 of L. maculans. As it is a dominant allele, it is beneficial and practical for hybrid utilization, because as long as one of the parental plants is homozygous in the $R \operatorname{lm} 1 / R \operatorname{lm} 1$ site, the hybrid seeds are consequently resistant. Therefore, validating the presence of Rlml in parental material facilitates the resistant hybrid breeding.

The overuse or consecutive use of one single $R$ gene tends to cause resistance breakdown, such as the 'sylvestris' resistance breakdown in Australia in 2003 (Van de Wouw et al., 2010). One solution to this is $R$ gene rotation, which should be built on identification of these $R$ genes. This study provides a foundation for that.

\section{Conflicts of Interest}

No potential conflict of interest relevant to this article was reported.

\section{Acknowledgments}

This work was supported by the National Key Research and Development Plan- the International Cooperation Project for China-Canada (2018YFE0108200); Modern Agroindustry Technology Research System of China (CARS12); Research and Public Service on Germplasm Resources of Main Crops.

\section{Electronic Supplementary Material}

Supplementary materials are available at The Plant Pathology Journal website (http://www.ppjonline.org/).

\section{References}

Ansan-Melayah, D., Balesdent, M. H., Delourme, R., Pilet, M. L., Tanguy, X., Renard, M. and Rouxel, T. 1998. Genes for racespecific resistance against blackleg disease in Brassica napus L. Plant Breed. 117:373-378.

Basunanda, P., Radoev, M., Ecke, W., Friedt, W., Becker, H. C. and Snowdon, R. J. 2010. Comparative mapping of quantitative trait loci involved in heterosis for seedling and yield traits in oilseed rape (Brassica napus L.). Theor. Appl. Genet. 120:271-281.

Delourme, R., Chèvre, A. M., Brun, H., Rouxel, T., Balesdent, M. H., Dias, J. S., Salisbury, P., Renard, M. and Rimmer, S. R. 2006. Major gene and polygenic resistance to Leptosphaeria maculans in oilseed rape (Brassica napus). Eur. J. Plant Pathol. 114:41-52.
Doyle, J. J. and Doyle, J. L. 1990. Isolation of plant DNA from fresh tissues. Focus 12:13-15.

Fernando, W. G. D., Zhang, X. and Amarasinghe, C. C. 2016. Detection of Leptosphaeria maculans and Leptosphaeria biglobosa causing blackleg disease in canola from Canadian canola seed lots and dockage. Plants 5:12.

Fitt, B. D. L., Brun, H., Barbetti, M. J. and Rimmer, S. R. 2006. World-wide importance of phoma stem canker (Leptosphaeria maculans and L. biglobosa) on oilseed rape (Brassica napus). Eur. J. Plant Pathol. 114:3-15.

Fitt, B. D. L., Hu, B. C., Li, Z. Q., Liu, S. Y., Lange, R. M., Kharbanda, P. D., Butterworth, M. H. and White, R. P. 2008. Strategies to prevent spread of Leptosphaeria maculans (phoma stem canker) onto oilseed rape crops in China; costs and benefits. Plant Pathol. 57:652-664.

Fu, F., Liu, X., Wang, R., Zhai, C., Peng, G., Yu, F. and Fernando, W. G. D. 2019. Fine mapping of Brassica napus blackleg resistance gene $R \operatorname{lm} 1$ through bulked segregant RNA sequencing. Sci. Rep. 9:14600.

Gan, L., Sun, X., Jin, L., Wang, G., Xu, J., Wei, Z. and Fu, T. 2003. Establishment of math models of NIRS analysis for oil and protein contents in seed of Brassica napus. Sci. Agric. Sin. 36:1609-1613 (in Chinese).

Howlett, B. J. 2004. Current knowledge of the interaction between Brassica napus and Leptosphaeria maculans. Can. J. Plant Pathol. 26:245-252.

Kutcher, H. R., Yu, F. and Brun, H. 2010. Improving blackleg disease management of Brassica napus from knowledge of genetic interactions with Leptosphaeria maculans. Can. J. Plant Pathol. 32:29-34.

Larkan, N. J., Lydiate, D. J., Parkin, I. A. P., Nelson, M. N., Epp, D. J., Cowling, W. A., Rimmer, S. R. and Borhan, M. H. 2013. The Brassica napus blackleg resistance gene LepR 3 encodes a receptor-like protein triggered by the Leptosphaeria maculans effector AVRLM1. New Phytol. 197:595-605.

Larkan, N. J., Ma, L. and Borhan, M. H. 2015. The Brassica napus receptor-like protein RLM2 is encoded by a second allele of the LepR3/Rlm 2 blackleg resistance locus. Plant Biotechnol. J. 13:983-992.

Larkan, N. J., Ma, L., Haddadi, P., Buchwaldt, M., Parkin, I. A. P., Djavaheri, M. and Borhan, M. H. 2020. The Brassica napus wall-associated kinase-like (WAKL) gene $R \operatorname{lm} 9$ provides race-specific blackleg resistance. Plant J. 104:892-900.

Liu, Z., Latunde-Dada, A. O., Hall, A. M. and Fitt, B. D. L. 2014. Phoma stem canker disease on oilseed rape (Brassica napus) in China is caused by Leptosphaeria biglobosa 'brassicae'. Eur. J. Plant Pathol. 140:841-857.

Marcroft, S. J., Van de Wouw, A. P., Salisbury, P. A., Potter, T. D. and Howlett, B. J. 2012. Effect of rotation of canola (Brassica napus) cultivars with different complements of blackleg resistance genes on disease severity. Plant Pathol. 61:934-944.

Semagn, K., Babu, R., Hearne, S. and Olsen, M. 2014. Single nucleotide polymorphism genotyping using kompetitive allele specific PCR (KASP): overview of the technology and its 
application in crop improvement. Mol. Breed. 33:1-14.

Sun, L., Wang, X., Yu, K., Li, W., Peng, Q., Chen, F., Zhang, W., Fu, S., Xiong, D., Chu, P., Guan, R. and Zhang, J. 2018. Mapping of QTLs controlling seed weight and seed-shape traits in Brassica napus L. using a high-density SNP map. Euphytica 214:228.

Van de Wouw, A. P., Cozijnsen, A. J., Hane, J. K., Brunner, P. C., McDonald, B. A., Oliver, R. P. and Howlett, B. J. 2010. Evolution of linked avirulence effectors in Leptosphaeria maculans is affected by genomic environment and exposure to resistance genes in host plants. PLoS Pathog. 6:e1001180.

Zhang, X., Peng, G., Kutcher, H. R., Balesdent, M.-H., Delourme, R. and Fernando, W. G. D. 2016a. Breakdown of Rlm3 resis- tance in the Brassica napus-Leptosphaeria maculans pathosystem in western Canada. Eur. J. Plant Pathol. 145:659-674.

Zhang, X., Peng, G., Parks, P., Hu, B., Li, Q., Jiang, L., Niu, Y., Huang, S. and Fernando, W. G. D. 2016b. Identifying seedling and adult plant resistance of Chinese Brassica napus germplasm to Leptosphaeria maculans. Plant Pathol. 66:752762.

Zhang, X., White, R. P., Demir, E., Jedryczka, M., Lange, R. M., Islam, M., Li, Z. Q., Huang, Y. J., Hall, A. M., Zhou, G., Wang, Z., Cai, X., Skelsey, P. and Fitt, B. D. L. 2014. Leptosphaeria spp., phoma stem canker and potential spread of L. maculans on oilseed rape crops in China. Plant Pathol. 63:598-612. 